\title{
FORTY-FOURTH ANNUAL LIST OF PAPERS
}

READ BEFORE THE AMERICAN MATHEMATICAL SOCIETY AND SUBSEQUENTLY PUBLISHED, INCLUDING REFERENCE TO THE PLACES OF PUBLICATION

Adams, C. R., and Lewy, Hans. On convergence in length. Read Feb. 23, 1935. Duke Mathematical Journal, vol. 1, No. 1 (March, 1935), pp. 19-26.

Albert, A. A. A note on the Poincaré theorem on impure Riemann matrices. Read March 30, 1934. Annals of Mathematics, (2), vol. 36, No. 1 (Jan., 1935), pp. 151-156.

- On cyclic fields. Read Sept. 7, 1934. Transactions of this Society, vol. 37, No. 3 (May, 1935), pp. 454-462.

- Involutorial simple algebras and real Riemann matrices. Read Nov.30, 1934, and April 20, 1935. Annals of Mathematics, (2), vol. 36, No. 4 (Oct., 1935), pp. 886-964.

Ballantine, J. P. A proof of E. H. Moore's equivalence. Read Aug. 31, 1932. This Bulletin, vol. 41, No. 12 (Dec., 1935), pp. 853-856.

Barber, S. F., and Zariski, Oscar. Reducible exceptional curves of the first kind. Read March 30, 1934. American Journal of Mathematics, vol. 57, No. 1 (Jan., 1935), pp. 119-141.

Basoco, M. A. On a certain identity due to Hermite. Read Nov. 30, 1934. American Mathematical Monthly, vol. 42, No. 5 (May, 1935), pp. 310-314.

Basoco, M. A., and Bell, E. T. Further theta expansions useful in arithmetic. Read Nov. 30, 1934. American Journal of Mathematics, vol. 57, No. 1 (Jan., 1935), pp. 1-10.

Basye, R. E. Concerning two internal properties of plane continua. Read April 20, 1935. This Bulletin, vol. 41, No. 10 (Oct., 1935), pp. 670-674.

- Simply connected sets. Read Oct. 28, 1933. Transactions of this Society, vol. 38, No. 2 (Sept., 1935), pp. 341-356.

Bateman, Harry. A partial differential equation connected with the functions of the parabolic cylinder. Read Dec. 2, 1933. This Bulletin, vol. 41, No. 12 (Dec., 1935), pp. 884-893.

Bell, E. T. Ternary arithmetical identities. Read Oct. 27, 1934. This Bulletin, vol. 41, No. 2 (Feb., 1935), pp. 85-91.

$-A$ revision of the algebra of Lucas functions. Read Dec. 1, 1934. Annals of Mathematics, (2), vol. 36, No. 3 (July, 1935), pp. 733-742.

- General relations between Bernoulli, Euler, and allied polynomials. Read Sept. 13, 1935. Transactions of this Society, vol. 38, No. 3 (Nov., 1935), pp. 493-500.

- See Basoco, M. A.

Bell, P.O. Tetrahedra associated with canonical expansions for a curved surface. Read April 6, 1935. This Bulletin, vol. 41, No. 6 (June, 1935), pp. 353-355.

Bernstein, B. A. On finite Boolean algebras. Read June 20, 1934. American Journal of Mathematics, vol. 57, No. 4 (Oct., 1935), pp. 733-742.

Bernstein, Felix. Principles of probability in the natural sciences. Read Dec. 27, 1933. Journal of Mathematics and Physics, Massachusetts Institute of Technology, vol. 14, No. 1 (March, 1935), pp. 28-35.

Binney, J. H. An elliptic system of integral equations on summable functions. 
Read Aug. 31, 1932. Transactions of this Society, vol. 37, No. 2 (March, 1935), pp. 254-265.

Birkhoff, Garrett. Orthogonality in linear vector spaces. Read Oct. 27, 1934. Duke Mathematical Journal, vol. 1, No. 2 (June, 1935), pp. 169-172.

Combinatorial relations in projective geometries. Read March 30, 1934. Annals of Mathematics, (2), vol. 36, No. 3 (July, 1935), pp. 743-748.

Integration of functions with values in a Banach space. Read Sept. 4, 1934. Transactions of this Society, vol. 38, No. 2 (Sept., 1935), pp. 357-378.

- Abstract linear dependence and lattices. Read April 20, 1935. American Journal of Mathematics, vol. 57, No. 4 (Oct., 1935), pp. 800-804.

- On the structure of abstract algebras. Read Oct. 27, 1934, and Nov. 30, 1934. Proceedings of the Cambridge Philosophical Society, vol. 31, part 4 (Oct., 1935), pp. 433-454.

Birkhoff, G. D., and Hestenes, M. R. Natural isoperimetric conditions in the calculus of variations. Read April 20, 1935. Duke Mathematical Journal, vol. 1, No. 2 (June, 1935), pp. 198-286.

Black, Amos. Further non-involutorial Cremona space transformations contained in a special linear complex. Read Dec. 27, 1933. This Bulletin, vol. 41, No. 8 (Aug., 1935), pp. 508-514.

Blumenthal, L. M. Concerning spherical spaces. Read March 30, 1934. American Journal of Mathematics, vol. 57, No. 1 (Jan., 1935), pp. 51-61.

Bochner, Salomon. Summation of multiple Fourier series by spherical means. Read April 20, 1935. Proceedings of the National Academy of Sciences, vol. 21, No. 6 (June, 1935), pp. 353-355.

Bochner, Salomon, and von Neumann, John. Almost periodic functions in groups. II. Read Dec. 28, 1934. Transactions of this Society, vol. 37, No. 1 (Jan., 1935), pp. 21-50.

Bompiani, Enrico. Geometrie Riemanniane di specie superiore. Read June 21, 1933. Memorie della Classe di Scienze Fisiche Matematiche e Naturali della R. Accademia d'Italia, vol. 6, No. 8 (Jan., 1935), pp. 269-520.

Brahana, H. R. Metabelian groups and trilinear forms. Read April 19, 1935. Duke Mathematical Journal, vol. 1, No. 2 (June, 1935), pp. 185-197.

Metabelian groups and pencils of bilinear forms. Read Sept. 4, 1934. American Journal of Mathematics, vol. 57, No. 3 (July, 1935), pp. 645667.

Note on irreducible quartic congruences. Read April 7, 1934. Transactions of this Society, vol. 38, No. 2 (Sept., 1935), pp. 395-400.

Brauer, Richard. Über die Kleinsche Theorie der algebraischen Gleichungen. Read Dec. 27, 1933. Mathematische Annalen, vol. 110, No. 4 (Nov., 1934), pp. $473-500$.

Brown, A. B. Functional dependence. Read Oct. 27, 1934. Transactions of this Society, vol. 38, No. 2 (Sept., 1935), pp. 379-394.

- On the locus of an analytic equation in the real plane. Read Feb. 23, 1935. This Bulletin, vol. 41, No. 12 (Dec., 1935), pp. 881-884.

Brown, A. B., and Halperin, Morris. On certain area-preserving maps. Read March 30, 1934. Annals of Mathematics, (2), vol. 36, No. 4 (Oct., 1935), pp. 833-837. 
Brown, B. H. Conformal and equiareal world maps. Read Dec. 27, 1933. American Mathematical Monthly, vol. 42, No. 4 (April, 1935), pp. 212-223.

Bumer, C. T. Systems of dynamics with hysteresis effects of the Fredholm type. Read Dec. 30, 1929. Abstracts of Doctor's Dissertations, Ohio State University, No. 7 (1931), pp. 21-26.

Burington, R.S. On the equivalence of quadrics in m-affine $n$-space and its relation to the equivalence of $2 m$-pole networks. Read Dec. 27, 1934. Transactions of this Society, vol. 38, No. 1 (July, 1935), pp. 163-176.

- A classification of plane cubic curves under the affine group by means of arithmetic invariants. Read Dec. 1, 1933. Tôhoku Mathematical Journal, vol. 41, No. 1 (Aug., 1935), pp. 188-202.

Cairns, S. S. Triangulation of the manifold of class one. Read Dec. 28, 1934. This Bulletin, vol. 41, No. 8 (Aug., 1935), pp. 549-552.

Cameron, R. H. Linear differential equations with almost periodic coefficients. Read Oct. 27, 1934. Duke Mathematical Journal, vol. 1, No. 3 (Sept., 1935), pp. 356-360.

Campbell, J. W. Note on the clock problem in relativity. Read Feb. 23, 1935. Philosophical Magazine, (7), vol. 19, (March, 1935), pp. 715-720.

Carlitz, Leonard. On certain functions connected with polynomials in a Galois field. Read April 14, 1933, and April 19, 1935. Duke Mathematical Journal, vol. 1, No. 2 (June, 1935), pp. 137-168.

- On the representation of a polynomial in a Galois field as the sum of an odd number of squares. Read Aug. 31, 1932, and Sept. 13, 1935. Duke Mathematical Journal, vol. 1, No. 3 (Sept., 1935), pp. 298-315.

- $A$ theorem on higher congruences. Read April 19, 1935. This Bulletin, vol. 41, No. 12 (Dec., 1935), pp. 844-846.

- On certain higher congruences. Read Sept. 13, 1935. This Bulletin, vol. 41, No. 12 (Dec., 1935), pp. 907-914.

Church, Randolph. Tables of irreducible polynomials for the first four prime moduli. Read Oct. 28, 1933. Annals of Mathematics, (2), vol. 36, No. 1 (Jan., 1935), pp. 198-209.

Churchill, R. V. Comparison of the temperatures in a solid and its scaled model. Read Dec. 27, 1934. Physics, vol. 6. No. 3 (March, 1935), pp. 100-104.

Coble, A. B. The geometry of the Weddle manifold $W_{p}$. Read Dec. 28, 1934. This Bulletin, vol. 41, No. 4 (April, 1935), pp. 209-222.

Cowgill, A. P. On the summability of a class of series of Jacobi polynomials. Read Nov. 30, 1934. This Bulletin, vol.41, No. 8 (Aug., 1935), pp. 541-549.

Craig, H. V. On a generalized tangent vector. Read June 20, 1934. American Journal of Mathematics, vol. 57, No. 2 (April, 1935), pp. 457-462.

Curtiss, John. Interpolation in regularly distributed points. Read Sept. 4, 1934. Transactions of this Society, vol. 38, No. 3 (Nov., 1935), pp. 458-473.

Davis, H. T. An extension to polygamma functions of a theorem of Gauss. Read Dec. 27, 1934. This Bulletin, vol. 41, No. 4 (April, 1935), pp. 243-247.

Deuring, M. F. Zetafunktionen quadratischer Formen. Read April 14, 1933. Journal für Mathematik, vol. 172, No. 4 (Feb., 1935), pp. 226-252.

Dickson, L. E. Cyclotomy and trinomial congruences. Read Dec. 28, 1934. Transactions of this Society, vol. 37, No. 3 (May, 1935), pp. 363-380. 
Cyclotomy when e is composite. Read April 20, 1935. Transactions of this Society, vol. 38, No. 2 (Sept., 1935), pp. 187-200.

Dix, C. H. Mechanical invariants of the sweeping-out process. Read June 20, 1934. This Bulletin, vol. 41, No. 2 (Feb., 1935), pp. 92-95.

Doob, J. L. The ranges of analytic functions. Read Feb. 25, 1933. Annals of Mathematics, (2), vol. 36, No. 1 (Jan., 1935), pp. 117-126.

Doob, J. L., and Koopman, B. O. On analytic functions with positive imaginary parts. Read Dec. 27, 1933. This Bulletin, vol. 40, No. 8 (Aug., 1934), pp. 601-605.

Dorroh, J. L. Concerning the direct product of algebras. Read March 30, 1934. Annals of Mathematics, (2), vol. 36, No. 4 (Oct., 1935), pp. 882-885.

Dorwart, H. L. Concerning certain reducible polynomials. Read Dec. 26, 1933. Duke Mathematical Journal, vol. 1, No. 1 (March, 1935), pp. 70-73.

Dresden, Arnold. $A$ program for mathematics. Read Dec. 31, 1934. American Mathematical Monthly, vol. 42, No. 4 (April, 1935), pp. 198-207.

Dressel, F. G. A generalization of harmonic functionals. Read Feb. 23, 1935. This Bulletin, vol. 41, No. 6 (June, 1935), pp. 381-388.

Dunford, Nelson. Integration in general analysis. Read April 20, 1935. Transactions of this Society, vol. 37, No. 3 (May, 1935), pp. 441-453. A correction to Integration in general analysis. Transactions of this Society, vol. 38, No. 3 (Nov., 1935), pp. 600-601.

On a theorem of Plessner. Read April 20, 1935. This Bulletin, vol. 41, No. 6 (June, 1935), pp. 356-358.

Dye, L. A. The number of trisecants of a space curve of order $m$ which meet an $i$-fold secant. Read Oct. 27, 1934. This Bulletin, vol. 41, No. 2 (Feb., 1935), pp. 109-110.

- Space involutorial transformations of the Geiser and Bertini types. Read Dec. 27, 1934. This Bulletin, vol. 41, No. 8 (Aug., 1935), pp. 515-520.

Einstein, Albert. Elementary derivation of the equivalence of mass and energy. Read Dec. 28, 1934. This Bulletin, vol. 41, No. 4 (April, 1935), pp. 223230.

Evans, G. C. Application of Poincarê's sweeping-out process. Read Dec. 29, 1932. Proceedings of the National Academy of Sciences, vol. 19, No. 4 (April, 1933), pp. 457-461.

- On potentials of positive mass. Part I. Read Dec. 29, 1932, Oct. 28, 1933, and Dec. 27, 1933. Transactions of this Society, vol. 37, No. 2 (March, 1935), pp. 226-253.

- On potentials of positive mass. Part II. Read Sept. 6, 1934, and Dec. 29, 1934. Transactions of this Society, vol. 38, No. 2 (Sept., 1935), pp. 201236.

Farrell O. J. On the expansion of harmonic functions in series of harmonic polynomials belonging to a simply connected region. Read Dec. 27, 1929, and Sept. 7, 1934. American Journal of Mathematics, vol. 57, No. 4 (Oct., 1935), pp. 883-890.

- On approximation by polynomials to a function analytic in a simply connected region. Read Sept. 4, 1934. This Bulletin, vol. 41, No. 10 (Oct., 1935), pp. 707-711. 
Fekete, Michael. Some generalizations of Paley's theorems on Fourier series with positive coefficients. Read Feb. 23, 1935. Transactions of this Society, vol. 38, No. 2 (Sept., 1935), pp. 237-249.

Feld, J. M. Analytic curves for which the chord equals the arc. Read April 3, 1931. American Mathematical Monthly, vol. 41, No. 9 (Nov., 1934), pp. 543546.

Fialkow, Aaron. Trajectories and lines of force. Read March 30, 1934. Transactions of this Society, vol. 38, No. 1 (July, 1935), pp. 89-105.

Finan, E. J. On the number theory of certain non-maximal domains of integrity of the total matric algebra of order 4 . Read Oct. 27, 1934. Duke Mathematical Journal, vol. 1, No. 4 (Dec., 1935), pp. 484-490.

Flexner, W. W. The intersection of chains on a topological manifold. Read Dec. 27, 1933. American Journal of Mathematics, vol. 57, No. 2 (April, 1935), pp. 309-321.

Flood, M. M. Division by non-singular matric polynomials. Read Feb. 25, 1933, and Dec. 27, 1933. Annals of Mathematics, (2), vol. 36, No. 4 (Oct., 1935), pp. 859-869.

Ford, L. R. On properties of regions which persist in the subregions bounded by level curves of the Green's function. Read Sept. 6, 1934. Duke Mathematical Journal, vol. 1, No. 1 (March, 1935), pp. 103-104.

Franklin, Philip. Two functional equations with integral arguments. Read April 3, 1931. American Mathematical Monthly, vol. 38, No. 3 (March, 1931), pp. 154-157.

_ A six-color problem. Read Sept. 7, 1934. Journal of Mathematics and Physics, Massachusetts Institute of Technology, vol. 13, No. 3 (Nov., 1934), pp. 363-369.

- On Minkowski's definition of length and area. Read Sept. 7, 1934. Journal of Mathematics and Physics, Massachusetts Institute of Technology, vol. 14, No. 2 (June, 1935), pp. 179-185.

- Derivatives of higher order as single limits. Read Dec. 27, 1933. This Bulletin, vol. 41, No. 8 (Aug., 1935), pp. 573-582.

Frink, Orrin. Differentiation of sequences. Read Dec. 27, 1934. This Bulletin, vol. 41, No. 8 (Aug., 1935), pp. 553-560.

Garabedian, H. L. A convergence factor theorem in the theory of summable series. Read Sept. 5, 1934. This Bulletin, vol. 41, No. 8 (Aug., 1935), pp. 583-592.

Garver, Raymond. A definition of group by three postulates. Read Dec. 1, 1934. American Journal of Mathematics, vol. 57, No. 2 (April, 1935), pp. 276280.

- Bieberbach's trisection method. Read Feb. 23, 1935. Scripta Mathematica, vol. 3, No. 3 (July, 1935), pp. 251-255.

- A note on Bieberbach's trisection method. Read Feb. 23, 1935. Journal für Mathematik, vol. 173, No. 4 (Sept., 1935), pp. 243-244.

Gergen, J. J., and Littauer, S. B. Continuity and summability for double Fourier series. Read Oct. 29, 1932. Transactions of this Society, vol. 38 , No. 3 (Nov., 1935), pp. 401-435.

Getchell, B. C. On the equivalence of two methods of defining Stieltjes integrals. Read April 6, 1934. This Bulletin, vol. 41, No. 6 (June, 1935), pp. 413-418. 
Goldberg, Michael. The isoperimetric problem for polyhedra Read Dec. 28, 1931. Tôhoku Mathematical Journal, vol. 40, No. 1 (Jan., 1935), pp. 226-236.

Graves, L. M. Topics in the functional calculus. Read April 19, 1935. This Bulletin, vol. 41, No. 10 (Oct., 1935), pp. 641-662.

Gunder, D. F. Flexure problem for rectangular beams with slits. Read Dec. 1, 1933. Physics, vol. 6, No. 1 (Jan., 1935), pp. 38-42.

Hadlock, E. H. On the progressions associated with a ternary quadratic form. Read Oct. 29, 1932. American Journal of Mathematics, vol. 57, No. 2 (April, 1935), pp. 267-275.

Halperin, M. See Brown, A. B.

Hedlund, G. A. A metrically transitive group defined by the modular group. Read April 20, 1935. American Journal of Mathematics, vol. 57, No. 3 (July, 1935), pp. 668-678.

Heins, A. E. Note on the equation of heat conduction. Read Dec. 28, 1934. This Bulletin, vol. 41, No. 4 (April, 1935), pp. 253-258.

Herzog, Fritz. Systems of algebraic mixed difference equations. Read Oct. 27, 1934. Transactions of this Society, vol. 37, No. 2 (March, 1935), pp. 286-300.

Hestenes, M. R. See Birkhoff, G. D.

Hill, J. D. Some theorems on double limits. Read April 20, 1935. This Bulletin, vol. 41, No. 8 (Aug., 1935), pp. 521-527.

Hinrichsen, J. J. L. Note on potential theory in n-space. Read Dec. 1, 1933. American Journal of Mathematics, vol. 57, No. 4 (Oct., 1935), pp. 921927.

Hoel, P. G. Certain problems in the theory of closest approximation. Read June 23, 1933. American Journal of Mathematics, vol. 57, No. 4 (Oct., 1935), pp. 891-901.

Hollcroft, T. R. The web of quadric hypersurfaces in $r$ dimensions. Read March 30, 1934. This Bulletin, vol. 41, No. 2 (Feb., 1935), pp. 97-103.

Hopkins, Charles. Metabelian groups of order $p^{m}, p>2$. Read Dec. 27, 1933. Transactions of this Society, vol. 37, No. 1 (Jan., 1935), pp. 161-195.

Hotelling, Harold. Demand functions with limited budgets. Read June 20, 1934. Econometrica, vol. 3, No. 1 (Jan., 1935), pp. 66-78.

Hull, Ralph. A determination of all cyclotomic quintic fields. Read Dec. 27, 1933. Annals of Mathematics, (2), vol. 36, No. 2 (April, 1935), pp. 366372.

- Maximal orders in rational cyclic algebras of odd prime degree. Read April 19, 1935. Transactions of this Society, vol. 38 , No. 3 (Nov., 1935), pp. 515-530.

Humphreys, M. G. On the Waring problem with polynomial summands. Read Nov. 30, 1934. Duke Mathematical Journal, vol. 1, No. 3 (Sept., 1935), pp. 361-375.

Huntington, E. V. The inter-deducibility of the new Hilbert-Bernays theory and Principia Mathematica. Read Sept. 6, 1934. Annals of Mathematics, (2), vol. 36, No. 2 (April, 1935), pp. 313-324.

- Effective equality and effective implication in formal logic. Read April 20, 1935. Proceedings of the National Academy of Sciences, vol. 21, No. 5 (May, 1935), pp. 266-271. 
- Inter-relations among the four principal types of order. Read April 20, 1935. Transactions of this Society, vol. 38, No. 1 (July, 1935), pp. 1-9.

- The mathematical structure of Lewis's theory of strict implication. Read April 20, 1935. Fundamenta Mathematicae, vol. 25 (1935), pp. 147-156.

Huston, R. E. Asymptotic generalizations of Waring's theorem. Read April 6, 1934. Proceedings of the London Mathematical Society, (2), vol. 39, No. 2 (March, 1935), pp. 82-115.

Ingraham, M. H., and Wegner, K. W. The equivalence of pairs of Hermitian matrices. Read April 7, 1934, and Sept. 4, 1934. Transactions of this Society, vol. 38, No. 1 (July, 1935), pp. 145-162.

Jackson, Dunham. Mathematical principles in the theory of small samples. Read June 20, 1934. American Mathematical Monthly, vol. 42, No. 6 (JuneJuly, 1935), pp. 344-364.

Jacobson, Nathan. Rational methods in the theory of Lie algetras. Read Feb. 23, 1935. Annals of Mathematics, (2), vol. 36, No. 4 (Oct., 1935), pp. 875-881.

James, Glenn. On Fermat's last theorem. Read Dec. 2, 1933. American Mathematical Monthly, vol. 41, No. 7 (Aug.-Sept., 1934), pp. 419-424.

Jenkins, E. D. On the composition of quadratic forms. Read April 19, 1935. This Bulletin, vol. 41, No. 10 (Oct., 1935), pp. 719-726.

See MacDuffee, C. C.

Jessen, Borge. Some analytical problems relating to probability. Read Dec. 27, 1933. Journal of Mathematics and Physics, Massachusetts Institute of Technology, vol. 14, No. 1 (March, 1935), pp. 24-27.

Jessen, Borge, and Wintner, Aurel. Distribution functions and the Riemann zeta function. Read April 20, 1935. Transactions of this Society, vol. 38, No. 1 (July, 1935), pp. 48-88.

Jones, F. B. A theorem concerning locally peripherally separable spaces. Read June 20, 1934. This Bulletin, vol. 41, No. 6 (June, 1935), pp. 437-439.

Kaltenborn, H. S. On Stieltjes mean integrals. Read Dec. 2, 1933. Dissertation, Michigan. Ann Arbor, Edwards, 1934. 33 pp.

van Kampen, E. R. Topological characterizations of 2-dimensional manifolds. Read Dec. 27, 1933. Duke Mathematical Journal, vol. 1, No. 2 (March, 1935), pp. 74-93.

Kellogg, O. D., and Sullivan, M. M. The boundary values of potentials and their derivatives-their dependence on the boundary. Read Dec. 27, 1932. Memoirs of the American Academy of Arts and Sciences, vol. 18, No. 1 (July, 1935), pp. 1-47.

Kempner, A. J. On the complex roots of algebraic equations. Read Nov. 30, 1934. This Bulletin, vol. 41, No. 12 (Dec., 1935), pp. 809-843.

Kimball, B. F. Generalization of the Bernoulli polynomial of order one. Read June 23, 1933. This Bulletin, vol. 41, No. 12 (Dec., 1935), pp. 894-900.

Kittell, Irving. A group of operations on a partially colored map. Read June 20, 1934. This Bulletin, vol. 41, No. 6 (June, 1935), pp. 407-413.

Kleene, S. C. See Rosser, J. B.

Kogbetliantz, Ervand. Contribution à l'étude du saut d'une fonction donnée par son développement en série d'Hermite ou de Laguerre. Read April 20, 1935.

Transactions of this Society, vol. 38, No. 1 (July, 1935), pp. 10-47.

Koopman, B. O. See Doob, J. L. 
Krall, H. L. On some asymptotic relations for the characteristic values of the elliptic differential equations. Read Dec. 27, 1933. American Journal of Mathematics, vol. 57, No. 4 (Oct., 1935), pp. 907-917.

Kullback, Solomon. An application of characteristic functions to the distribution problem of statistics. Read Feb. 25, 1933. Annals of Mathematical Statistics, vol. 5, No. 4 (Dec., 1934), pp. 263-307.

- A note on the analysis of variance. Read Feb. 23, 1935. Annals of Mathematical Statistics, vol. 6, No. 2 (June, 1935), pp. 76-77.

- On the Bernoulli distribution. Read Nov. 30, 1934. This Bulletin, vol. 41, No. 12 (Dec., 1935), pp. 857-864.

Lane, E. P. Plane sections through an asymptotic tangent of a surface. Read April 20, 1935. This Bulletin, vol. 41, No. 4 (April, 1935), pp. 285-290.

- A canonical power series expansion for a surface. Read April 20, 1935. Transactions of this Society, vol. 37, No. 3 (May, 1935), pp. 463-482. The neighborhood of a sextactic point on a plane curve. Read Sept. 11, 1935. Duke Mathematical Journal, vol. 1, No. 3 (Sept., 1935), pp. 287-292.

Langer, R. E. On the asymptotic solutions of ordinary differential equations, with reference to the Stokes' phenomenon about a singular point. Read Sept. 6, 1934. Transactions of this Society, vol. 37, No. 3 (May, 1935), pp. 397416.

LaPaz, Lincoln. See Radó, Tibor.

Latimer, C. G. On ideals in generalized quaternion algebras and hermitian forms. Read April 19, 1935. Transactions of this Society, vol. 38, No. 3 (Nov., 1935), pp. 436-446.

Lehmer, D. H. Lacunary recurrence formulas for Bernoulli numbers. Read Dec. 27, 1933. Annals of Mathematics, (2), vol. 36, No. 3 (July, 1935), pp. 637-649.

- On Lucas's test for the primality of Mersenne's numbers. Read Feb. 23, 1935. Journal of the London Mathematical Society, vol. 10, No. 3 (July, 1935), pp. 162-165.

Lehmer, D. N. Law of reciprocity for tables of linear forms. Read Dec. 2, 1933. Tôhoku Mathematical Journal, vol. 40, No. 2 (April, 1935), pp. 405-407.

Levitski, Jakob. On automorphisms of certain rings. Read June 20, 1934. Annals of Mathematics, (2), vol. 36, No. 4 (Oct., 1935), pp. 984-992.

Lewy, Hans. A priori limitations for solutions of Monge-Ampère equations. Read Sept. 5, 1934. Transactions of this Society, vol. 37, No. 3 (May, 1935), pp. 417-434.

- See Adams, C. R.

Littauer, S. B. See Gergen, J. J.

Litzinger, Marie. A basis for residual polynomials in $n$ variables. Read Feb. 23, 1935. Transactions of this Society, vol. 37, No. 2 (March, 1935), pp. 216-225.

Lorch, E. R. Functions of self-adjoint transformations in Hilbert space. Read April 20, 1935. Acta Litterarum ac Scientiarum, vol. 7, No. 3 (July, 1935), pp. 136-146.

McCoy, N. H. On the rational canonical form of a function of a matrix. Read Dec. 28, 1934. American Journal of Mathematics, vol. 57, No. 3 (July, 1935), pp. 491-502. 
McEwen, W. H. Polynomials of best approximation associated with certain problems in two dimensions. Read Dec. 27, 1933. American Journal of Mathematics, vol. 57, No. 2 (April, 1935), pp. 367-381.

McShane, E. J. Existence theorems for double integral problems of the calculus of variations. Read Oct. 28, 1933. Transactions of this Society, vol. 38, No. 3 (Nov., 1935), pp. 549-563.

MacDuffee, C. C., and Jenkins, E. D. A substitute for the Euclid algorithm in algebraic fields. Read April 6, 1934. Annals of Mathematics, (2), vol. 36, No. 1 (Jan., 1935), pp. 40-45.

MacGregor, C. W. The potential function method for the solution of two-dimensional stress problems. Read April 20, 1935. Transactions of this Society, vol. 38, No. 1 (July, 1935), pp. 177-186.

MacLane, Saunders. Abgek ürate Beweise im Logikkalkul. Read Dec. 26, 1933. Inaugural-Dissertation, Göttingen, Hubert and Co., 1934.

- A logical analysis of mathematical structure. Read Dec. 27, 1933. The Monist, vol. 45, No. 1 (Jan., 1935), pp. 118-130.

- Some unique separation theorems for graphs. Read Sept. 7, 1934. American Journal of Mathematics, vol. 57, No. 4 (Oct., 1935), pp. 805-820.

Maier, Wilhelm. Transformation der kubischen Thetafunktion. Read April 6, 1934. Mathematische Annalen, vol. 111, No. 2 (April, 1935), pp. 183196.

Mayer, Walther. Die Differentialgeometrie der Untermannigfaltigkeiten des $R_{n}$ konstanter Krümmung. Read April 20, 1935. Transactions of this Society, vol. 38, No. 2 (Sept., 1935), pp. 267-309.

Miller, E. W. On the singularities of an analytic function. Read April 20, 1935. This Bulletin, vol. 41, No. 8 (Aug., 1935), pp. 561-565.

Montgomery, Deane. Non-separable metric spaces. Read Dec. 27, 1934. Fundamenta Mathematicae, vol. 25 (1935), pp. 527-533.

Moore, C. N. Mathematics and science. Read Dec. 31, 1934. Science, new series, vol. 81, No. 2089 (Jan. 11, 1935), pp. 27-32.

- On convergence factors for series summable by Nörlund means. Read Dec. 29, 1934. Proceedings of the National Academy of Sciences, vol. 21, No. 5 (May, 1935), pp. 263-266.

- On criteria for Fourier constants of L-integrable functions of several variables. Read Dec. 27, 1933, and Oct. 27, 1934. Duke Mathematical Journal, vol. 1, No. 3 (Sept., 1935), pp. 293-297.

Moore, R. L. A set of axioms for plane analysis situs. Read Nov. 28, 1931. Fundamenta Mathematicae, vol. 25 (1935), pp. 13-28.

Morse, Marston. Sufficient conditions in the problem of Lagrange without assumptions of normalcy. Read Sept. 6, 1934. Transactions of this Society, vol. 37, No. 1 (Jan., 1935), pp. 147-160.

— Instability and transitivity. Read Dec. 27, 1933. Journal de Mathématiques, vol. 14, No. 1 (Jan.-March, 1935), pp. 49-71.

Morse, Marston, and Van Schaack, G. B. The critical point theory under general boundary conditions. Read Sept. 6, 1934. Annals of Mathematics, (2), vol. 35, No. 3 (July, 1934), pp. 545-571.

- Abstract critical sets. Read Sept. 6, 1934. Proceedings of the National Academy of Sciences, vol. 21, No. 5 (May, 1935), pp. 258-263. 
Morrey, C. B. The topology of (path) surfaces. Read April 14, 1933. American Journal of Mathematics, vol. 57, No. 1 (Jan., 1935), pp. 17-50.

- An analytic characterization of surfaces of finite Lebesgue area. Read Dec. 27, 1932. American Journal of Mathematics, vol. 57, No. 3 (July, 1935), pp. 692-702.

Moursund, A. F. On summation of derived series of the conjugate Fourier series. Read Oct. 28, 1933. Annals of Mathematics, (2), vol. 36, No. 1 (Jan., 1935), pp. 182-193.

- On the rth derived conjugate function. Read Dec. 1, 1934. This Bulletin, vol. 41, No. 2 (Feb., 1935), pp. 131-136.

A note on Taylor's theorem. Read April 6, 1935. This Bulletin, vol. 41, No. 4 (April, 1935), pp. 231-232.

- On summation of derived series of the conjugate Fourier series. Read Oct. 27, 1934. American Journal of Mathematics, vol. 57, No. 4 (Oct., 1935), pp. 854-860.

Murray, F. J. Linear transformations between Hilbert spaces and the application of this theory to linear partial differential equations. Read March 31, 1934. Transactions of this Society, vol. 37, No. 2 (March, 1935), pp. 301-338.

Myers, S. B. Riemannian manifolds in the large. Read Dec. 27, 1933. Duke Mathematical Journal, vol. 1, No. 1 (March, 1935), pp. 39-49.

- Connections between differential geometry and topology. I: Simply connected surfaces. Read Dec. 28, 1934, and April 19, 1935. Proceedings of the National Academy of Sciences, vol. 21, No. 4 (April, 1935), pp. 225227.

von Neumann, John. On complete topological spaces. Read Dec. 28, 1934. Transactions of this Society, vol. 37, No. 1 (Jan., 1935), pp. 1-20.

- Zur Operatorenmethode in der Klassischen Mechanik. Read Dec. 30, 1932. Annals of Mathematics, (2), vol. 33, No. 3 (July, 1932), pp. 587-642.

- See Bochner, Salomon.

Nichols, G. D. The explicit arithmetized Fourier series developments for certain doubly periodic functions of the second kind. Read June 23, 1933. Tôhoku Mathematical Journal, vol. 40, No. 1 (Jan., 1935), pp. 252-258.

- The arithmetized expansions for certain doubly periodic functions of the third kind. Read Nov. 30, 1934. This Bulletin, vol. 41, No. 6 (June, 1935), pp. 361-365.

Oakley, C. O. Semi-linear equations. Read April 3, 1931, Dec. 28, 1931, and Dec. 27, 1933. Tôhoku Mathematical Journal, vol. 41, No. 1 (Aug., 1935), pp. 52-69.

Oberg, E. N. The approximate solution of integral equations. Read June 23, 1933. This Bulletin, vol. 41, No. 4 (April, 1935), pp. 276-284.

Offord, A. C. On Fourier transforms. III. Read Feb. 23, 1935. Transactions of this Society, vol. 38, No. 2 (Sept., 1935), pp. 250-266.

Oldenburger, Rufus. Canonical triples of bilinear forms. Read April 7, 1934. Tôhoku Mathematical Journal, vol. 41, No. 1 (Aug., 1935), pp. 216-221.

Olds, E. G. Distributions of greatest variates, least variates, and intervals of variation in samples from a rectangular universe. Read Dec. 27, 1934. This Bulletin, vol. 41, No. 4 (April, 1935), pp. 297-304. 
Ore, Oystein. Einige Bemerkungen über Irreduzibilität. Read March 31, 1934. Jahresberichte der Deutschen Mathematiker-Vereinigung, vol. 44, Nos. 5-8 (1934), pp. 147-151.

On the foundation of abstract algebra. I. Read Oct. 27, 1934. Annals of Mathematics, (2), vol. 36, No. 2 (April, 1935), pp. 406-437.

Pall, Gordon. On the order invariants of integral quadratic forms. Read April 15, 1933, and June 20, 1934. Quarterly Journal of Mathematics, Oxford Series, vol. 6, No. 21 (March, 1935), pp. 30-51.

- A new solution of the Gauss problem on $h\left(s^{2} d\right) / h(d)$. Read April 6, 1935. This Bulletin, vol. 41, No. 6 (June, 1935), pp. 373-374.

— Binary quadratic discriminants differing by square factors. Read Sept. 13, 1935. American Journal of Mathematics, vol. 57, No. 4 (Oct., 1935), pp. 789-799.

Perkins, F. W. The Dirichlet problem for domains with multiple boundary points. Read Dec. 26, 1933. Transactions of this Society, vol. 38, No. 1 (July, 1935), pp. 106-144.

Prenowitz, Walter. The characterization of plane collineations in terms of homologous families of lines. Read March 26, 1932, and Oct. 27, 1934. Transactions of this Society, vol. 38, No. 3 (Nov., 1935), pp. 564-599.

Price, G. B. On reversible dynamical systems. Read Feb. 25, 1933. Transactions of this Society, vol. 37, No. 1 (Jan., 1935), pp. 51-79.

Rademacher, Hans. Über die Anzahl der Primzahlen eines reell-quadratischen Zahlkörpers, deren Konjugierte unterhalb gegebener Grenzen liegen. Read Dec. 29, 1934. Acta Arithmetica, vol. 1, No. 1 (Feb., 1935), pp. 67-77.

Rad6, Tibor. On convex functions. Read April 7, 1934. Transactions of this Society, vol. 37, No. 2 (March, 1935), pp. 266-285.

- The isoperimetric inequality on the sphere. Read April 20, 1935. American Journal of Mathematics, vol. 57, No. 4 (Oct., 1935), pp. 765-770.

Rad6, Tibor, and LaPaz, Lincoln. On a converse of the Kneser transversality theorem. Read April 7, 1934. Annals of Mathematics, (2), vol. 36, No. 3 (July, 1935), pp. 749-769.

Randolph, J. F. Carathéodory measure and a generalization of the Gauss-Green lemma. Read Oct. 27, 1934. Transactions of this Society, vol. 38, No. 3 (Nov., 1935), pp. 531-548.

Reid, W. T. Discontinuous solutions of the non-parametric problem of Mayer in the calculus of variations. Read June 23, 1933. American Journal of Mathematics, vol. 57, No. 1 (Jan., 1935), pp. 69-93.

- The theory of the second variations for the non-parametric problem of Bolza. Read Sept. 5, 1934. American Journal of Mathematics, vol. 57, No. 3 (July, 1935), pp. 573-586.

- $A$ certain three-dimensional continuum. Read Feb. 23, 1935. This Bulletin, vol. 41, No. 10 (Oct., 1935), pp. 683-684.

- A theorem on plane continua. Read Dec. 28, 1934. This Bulletin, vol. 41, No. 10 (Oct., 1935), pp. 684-688.

Richardson, Moses. On homology characters of symmetric products. Read Feb. 25, 1933. Duke Mathematical Journal, vol. 1 No. 1 (March, 1935), pp. $50-69$. 
The relative connectivities of symmetric products. Read Feb. 23, 1935. This Bulletin, vol. 41, No. 8 (Aug., 1935), pp. 528-534.

Ritt, J. F. Systems of algebraic differential equations. Read March 31, 1934. Annals of Mathematics, (2), vol. 36, No. 2 (April, 1935), pp. 293-302. Jacobi's problem on the order of a system of differential equations. Read March 31, 1934. Annals of Mathematics, (2), vol. 36, No. 2 (April, 1935), pp. 303-312.

Robertson, M. S. On the coefficients of a typically-real function. Read Feb. 23, 1935. This Bulletin, vol. 41, No. 8 (Aug., 1935), pp. 565-572.

Robinson, Robin. Note on the geometric interpretation of the vanishing of a certain projective invariant of two conics. Read Dec. 27, 1934. This Bulletin, vol. 41, No. 6 (June, 1935), pp. 399-406.

Robinson, R. M. The Bloch constant $\mathfrak{A}$ for a schlicht function. Read Oct. 27, 1934. This Bulletin, vol. 41, No. 8 (Aug., 1935), pp. 535-540.

Rosser, J. B. A mathematical logic without variables. I. Read Oct. 28, 1933. Annals of Mathematics, (2), vol. 36, No. 1 (Jan., 1935), pp. 127-150.

Rosser, J. B., and Kleene, S. C. The inconsistency of certain formal logics. Read Dec. 27, 1934. Annals of Mathematics, (2), vol. 36, No. 3 (July, 1935), pp 630-636.

Rutt, N. E. Prime ends and indecomposability. Read Dec. 27, 1929, and Sept. 7, 1934. This Bulletin, vol. 41, No. 4 (April, 1935), pp. 265-273.

Schoenberg, I. J. Remarks to Maurice Fréchet's article: Sur la définition d'une classe d'espaces vectoriels distanciés applicables vectoriellement sur l'espace de Hilbert. Read Feb. 23, 1935. Annals of Mathematics, (2), vol. 36, No. 3 (July, 1935), pp. 724-732.

Schwid, Nathan. The asymptotic forms of the Hermite and Weber functions. Read April 6, 1934. Transactions of this Society, vol. 37, No. 2 (March, 1935), pp. 339-362.

Sewell, W. E. Degree of approximation by polynomials to continuous functions. Read Dec. 28, 1934. This Bulletin, vol. 41, No. 2 (Feb., 1935), pp. 111-117. Generalized derivatives and approximation. Read Dec. 27, 1934. Proceedings of the National Academy of Sciences, vol. 21, No. 5 (May, 1935), pp. $255-258$.

Sheffer, I. M. Note on non-analytic functions. Read April 18, 1930. This Bulletin, vol. 41, No. 6 (June, 1935), pp. 367-372.

- Concerning some methods of best approximation and a theorem of Birkhoff. Read Dec. 27, 1933. American Journal of Mathematics, vol. 57, No. 3 (July, 1935), pp. 587-614.

- A differential equation for Appell polynomials. Read April 20, 1935. This Bulletin, vol. 41, No. 12 (Dec., 1935), pp. 914-923.

Shohat, J. A. On the development of functions in series of orthogonal polynomials. Read Sept. 6, 1934. This Bulletin, vol. 41, No. 2 (Feb., 1935), pp. 49-82.

Simmons, H. A. The classification and general solution of certain Diophantine problems which involve special systems of equations of the second degree. Read Feb. 23, 1935. American Mathematical Monthly, vol. 42, No. 2 (Feb., 1935), pp. 94-101.

Sinkov, Abraham. A property of cyclic substitutions of even degree. Read Oct. 28, 
1933. American Mathematical Monthly, vol. 42, No. 3 (March, 1935), pp. $145-149$.

- A set of defining relations for the simple group of order 1092. Read Feb. 23, 1935. This Bulletin, vol. 41, No. 4 (April, 1935), pp. 237-240.

Smith, P. A. The fundamental group of group manifolds. Read Sept. 6, 1934. Annals of Mathematics, (2), vol. 36, No. 1 (Jan., 1935), pp. 210-229.

Suckau, J. W. T. On uniform convergence. Read April 6, 1934. American Journal of Mathematics, vol. 57, No. 3 (July, 1935), pp. 549-561.

Sullivan, M. M. See Kellogg, O. D.

Synge, J. L. Some intrinsic and derived vectors in a Kawaguchi space. Read Dec. 27, 1934. American Journal of Mathematics, vol. 57, No. 3 (July, 1935), pp. 679-691.

- Mechanical models of spaces with positive-definite line-element. Read Dec. 27, 1933. Annals of Mathematics, (2), vol. 36, No. 3 (July, 1935), pp. 650656.

Principal null-directions in space-time defined by an clectromagnetic field. Read Dec. 29, 1934. University of Toronto Studies, Applied Mathematics Series, No. 1 (1935).

Szász, Otto. Generalization of two theorems of Hardy and Littlewood on power series. Read Feb. 23, 1935. Duke Mathematical Journal, vol. 1, No. 1 (March, 1935), pp. 105-111.

- Convergence properties of Fourier series. Read Sept. 6, 1934. Transactions of this Society, vol. 37, No. 3 (May, 1935), pp. 483-500.

Szegö, Gabriel. A problem concerning orthogonal polynomials. Read Dec. 29, 1934. Transactions of this Society, vol. 37, No. 1 (Jan., 1935), pp. 196-206.

Tartler, Alexander. On a certain class of orthogonal polynomials. Read Oct. 31, 1931. American Journal of Mathematics, vol. 57, No. 3 (July, 1935), pp. 627-644.

Taylor, A. E. A reduced set of postulates for abstract Hilbert space. Read Dec. 1, 1934. This Bulletin, vol. 41, No. 6 (June, 1935), pp. 439-448.

Terry, Henrietta. Abelian subgroups of order $p^{m}$ of the I-groups of the abelian groups of order $p^{n}$ and type $1,1, \cdots$. Read Sept. 7, 1934. Duke Mathematical Journal, vol. 1, No. 1 (March, 1935), pp. 27-34.

Thomas, T. Y. Algebraic characterizations in complex differential geometry. Read Sept. 13, 1935. Transactions of this Society, vol. 38, No. 3 (Nov., 1935), pp. 501-514.

Thompson, W. R. On the theory of apportionment. Read Dec. 27, 1933. American Journal of Mathematics, vol. 57, No. 2 (April, 1935), pp. 450-456.

Tompkins, C. B. Linear connections in normal space to a variety in euclidean space. Read April 19, 1935. This Bulletin, vol. 41, No. 12 (Dec., 1935), pp. 931-936.

Trjitzinsky, W. J. The general case of linear integro-differential equations. Read Dec. 27, 1933. Proceedings of the National Academy of Sciences, vol. 20, No. 12 (Dec., 1934), pp. 668-671.

- Laplace integrals and factorial series in the theory of linear differential and linear difference equations. Read Dec. 27, 1934. Transactions of this Society, vol. 37, No. 1 (Jan., 1935), pp. 80-146. 
A theory of quasi-analytic classes. Read Dec. 27, 1932. Mathematische Zeitschrift, vol. 39, No. 4 (Jan., 1935), pp. 560-589.

Trump, P. L. On a reduction of a matrix by the group of matrices commutative with a given matrix. Read Sept. 4, 1934. This Bulletin, vol. 41, No. 6 (June, 1935), pp. 374-380.

Uhlenbeck, G. E. The probability of position in a canonical ensemble. Read Dec. 27, 1933. Journal of Mathematics and Physics, Massachusetts Institute of Technology, vol. 14, No. 1 (March, 1935), pp. 10-16.

Uspensky, J. V. On the expansion of the remainder in the Nerwton-Cotes formula. Read Sept. 7, 1934. Transactions of this Society, vol. 37, No. 3 (May, 1935), pp. 381-396.

Van Schaack, G. B. See Morse, Marston.

Vickery, C. W. Spaces in which there exist uncountable convergent sequences of points. Read Oct. 28, 1933. Tôhoku Mathematical Journal, vol. 40, No. 1 (Jan., 1935), pp. 1-26.

Walsh, J. L. Lemniscates and equipotential curves of Green's functions. Read June 20, 1934. American Mathematical Monthly, vol. 42, No. 1 (Jan., 1935), pp. 1-17.

- Interpolation and approximation by rational functions in the complex domain. Read Dec. 27, 1932, April 14, 1933, Dec. 27, 1933, March 31, 1934, Dec. 27, 1934, and Feb. 23, 1935. American Mathematical Society Colloquium Publications, vol. 20, 1935. 9+382 pp.

Ward, L. E. A third-order irregular boundary value problem and the associated series. Read Feb. 25, 1933. American Journal of Mathematics, vol. 57, No. 2 (April, 1935), pp. 345-362.

Ward, Morgan. Note on the period of a mark in a finite field. Read June 20, 1934. This Bulletin, vol. 40, No. 4 (April, 1934), pp. 279-281.

- Conditions for factorization in a set closed under a single operation. Read Dec. 27, 1934. Annals of Mathematics, (2), vol. 36, No. 1 (Jan., 1935), pp. 36-39.

- A determination of all possible systems of strict implication. Read Dec. 27, 1934. American Journal of Mathematics, vol. 57, No. 2 (April, 1935), pp. 261-266.

- An enumerative problem in the arithmetic of linear recurring series. Read Dec. 27, 1934. Transactions of this Society, vol. 37, No. 3 (May, 1935), pp. 435-440.

The diophantine equation $X^{2}-D Y^{2}=Z^{M}$. Read Dec. 2, 1933. Transactions of this Society, vol. 38, No. 3 (Nov., 1935), pp. 447-457.

Warschawski, S. E. On the higher derivatives at the boundary in conformal mapping. Read Oct. 27, 1934. Transactions of this Society, vol. 38, No. 2 (Sept., 1935), pp. 310-340.

Webb, D. L. Generation of an n-valued logic by one binary operation. Read April 6, 1935. Proceedings of the National Academy of Sciences, vol. 21, No. 5 (May, 1935), pp. 252-254.

Weeks, D. W. Three mathematical methods of analyzing polarized light. Read Sept. 12, 1930. Journal of Mathematics and Physics, Massachusetts Institute of Technology, vol. 13, No. 4 (Dec., 1934), pp. 371-379. 
- A study of sixteen coherency matrices. Read Sept. 12, 1930. Journal of Mathematics and Physics, Massachusetts Institute of Technology, vol. 13, No. 4 (Dec., 1934), pp. 380-386.

Wegner, K. W. See Ingraham, M. H.

Weida, F. M. On measures of contingency. Read Dec. 1, 1933. Annals of Mathematical Statistics, vol. 5, No. 4 (Dec., 1934), pp. 308-320.

Weisner, Louis. Irreducibility of polynomials of degree $n$ which assume the same value $n$ times. Read Sept. 7, 1934. This Bulletin, vol. 41, No. 4 (April, 1935), pp. 248-252.

- Abstract theory of inversion of finite sums. Read Feb. 23, 1935. Transactions of this Society, vol. 38, No. 3 (Nov., 1935), pp. 474-484.

- Some properties of prime-power groups. Read Feb. 23, 1935. Transactions of this Society, vol. 38, No. 3 (Nov., 1935), pp. 485-492.

Whiteman, Albert. On the law of quadratic reciprocity. Read Feb. 23, 1935. This Bulletin, vol. 41, No. 6 (June, 1935), pp. 359-360.

Whitney, Hassler. On the abstract properties of linear dependence. Read Sept. 7, 1934. American Journal of Mathematics, vol. 57, No. 3 (July, 1935), pp. 509-533.

Whyburn, G. T. Concerning continua of finite degree and local separating points. Read Oct. 27, 1934. American Journal of Mathematics, vol. 57, No. 1 (Jan., 1935), pp. 11-16.

- A decomposition theorem for closed sets. Read Oct. 27, 1934. This Bulletin, vol. 41, No. 2 (Feb., 1935), pp. 95-96.

Concerning perfect sets. Read Dec. 28, 1934. Duke Mathematical Journal, vol. 1, No. 1 (March, 1935), pp. 35-38.

— Regular convergence and monotone transformations. Read Sept. 13, 1935. American Journal of Mathematics, vol. 57, No. 4 (Oct., 1935), pp. 902906.

- On sequences and limiting sets. Read Dec. 28, 1934, and April 20, 1935. Fundamenta Mathematicae, vol. 25 (1935), pp. 408-426.

Whyburn, W. M. A connectedness theorem in abstract sets. Read Dec. 1, 1934. This Bulletin, vol. 41, No. 6 (June, 1935), pp. 365-366.

Widder, D. V. An application of Laguerre polynomials. Read April 20, 1935. Duke Mathematical Journal, vol. 1, No. 2 (June, 1935), pp. 126-136.

Wilder, R. L. On free subsets of $E_{n}$. Read April 20,1935. Fundamenta Mathematicae, vol. 25 (1935), pp. 200-208.

Williams, A. R. Correspondences connected with a pencil of n-ics. Read April 6, 1935. This Bulletin, vol. 41, No. 12 (Dec., 1935), pp. 868-874.

Wilson, E. B. Boole's challenge problem. (A problem in probability.) Read June 20, 1934. Journal of the American Statistical Association, vol. 29, No. 187 (Sept., 1934), pp. 301-304.

- What is a proof? Read Dec. 28, 1934. Science, new series, vol. 81, No. 2103 (April 19, 1935), pp. 371-373.

Wilson, W. A. On certain types of continuous transformations of metric spaces. Read Sept. 7, 1934. American Journal of Mathematics, vol. 57, No. 1 (Jan., 1935), pp. 57-68.

On the imbedding of metric sets in euclidean space. Read Sept. 7, 1934. 
American Journal of Mathematics, vol. 57, No. 2 (April, 1935), pp. 322326.

Wintner, Aurel. See Jessen, Borge.

Wong, B. C. Certain contact properties of linear systems of hypersurfaces. Read June 20, 1934. Transactions of this Society, vol. 37, No. 2 (March, 1935), pp. 207-215.

Zariski, Oscar. See Barber, S. F.

Zippin, Leo. Countable torsion groups. Read Oct. 27, 1934. Annals of Mathematics, (2), vol. 36, No. 1 (Jan., 1935), pp. 86-99.

— Semi-compact spaces. Read Dec. 27, 1933. American Journal of Mathematics, vol. 57, No. 2 (April, 1935), pp. 327-341.

Zorn, Max. The automorphisms of Cayley's non-associative algebra. Read April 19, 1935. Proceedings of the National Academy of Sciences, vol. 21, No. 6 (June, 1935), pp. 355-358.

$A$ remark on method in transfinite algebra. Read Oct. 27, 1934. This Bulletin, vol. 41, No. 10 (Oct., 1935), pp. 667-670. 